\title{
Akuntansi Zakat PSAK 109 dalam Penguatan Good Corporate Lembaga Amil Zakat di Kabupaten Pamekasan
}

\author{
Sri Handayani \\ Fakultas Ekonomi Dan Bisnis Islam IAIN Madura \\ Email: andayani154@gmail.com
}

\begin{abstract}
Abstrak:
One of the three pillars for Muslims is the obligation to pay zakat according to provisions. Zakat is intended for people who are deficient. In Indonesia, poverty is still visible in some communities, this is what shows the role of zakat can contribute in breaking down poverty. Good and transparent management is an accountable financial responsibility. Indonesia has an accounting recording standard in the form of PSAK number 109 concerning zakat accounting. The purpose of this study is to analyze the accounting treatment of zakat PSAK 109 in strengthening good corporate governance of the Amil Zakat Institution. The results of his research show that the accountability report of the amil zakat party in the form of financial reports has been made, the accounting records of the institution understand the incoming and outgoing funds, the conversion of non-cash funds at market prices, incoming halal and non-halal funds and have followed the Law Republic of Indonesia Number 23 of 2011 concerning Management of Zakat although there are some things that are still not well understood.

[salah satu rukun ketiga bagi umat islam adalah kewajiban membayar zakat sesuai ketentuan. Zakat diperuntukan bagi masyarakat yang kekurangan. Di Indonesia masih terlihat kemiskinan di beberapa masyarakat, hal inilah yang menunjukkan peran zakat dapat ikut andil dalam mengurai kemiskinan tersebut. Pengelolaan yang baik dan transparan merupakan pertanggungjawaban keuangan yang akuntabel. Indonesia mempunyai standar pencatatan akuntansi berupa PSAK nomer 109 tentang akuntansi zakat Adapun tujuan penelitian ini adalah menganalisis perlakuan akuntansi zakat PSAK 109 dalam penguatan good corporate Lembaga Amil Zakat. Hasil penelitiannya menunjukkan bahwa laporan pertanggungjawaban pihak amil zakat berupa laporan keuangan sudah di buat, pencatatan akuntansi pihak lembaga sudah paham mengenai dana masuk dan dana keluar, konversi dana non tunai dengan harga pasar, yang masuk dana halal dan non halal serta telah mengikuti Undang-Undang Republik Indonesia Nomor 23 Tahun 2011 Tentang Pengelolaan Zakat meskipun ada beberapa hal yang masih belum dipahami dengan baik.]
\end{abstract}

Kata Kunci: Akuntansi Zakat; Good Corporate; Lembaga Amil zakat. 


\section{PENDAHULUAN}

Membayar zakat wajib dilakukan oleh setiap muslim berdasarkan kemampuan yang dimiliki. Rukun islam yang ketiga ini merupakan kewajiban yang harus dilakukan. Adanya zakat adalah bagian mutlak dari keislaman seseorang yang sering dianggap sebagai ma'lum min al-din bi al-dharurah. ${ }^{1}$ Menunaikan zakat merupakan bagian dalam rukun Islam. Zakat adalah harta yang wajib dikeluarkan oleh seorang muslim atau badan usaha untuk diberikan kepada yang berhak menerimanya sesuai dengan syariat Islam. ${ }^{2}$ Adanya kewajiban yang harus dikeluarkan bagi yang berhak mengeluarkan zakat maka seyogyanya hal tersebut harus dilakukan mengingat menunaikan zakat yang hukumnya wajib.

Zakat juga didefinisikan sebagai ibadah yang mengandung hikmah dan manfaat yang besar serta mulia berkaitan dengan orang yang berzakat (muzakki), penerimanya (mustahiq), harta yang dikeluarkan zakatnya, maupun bagi masyarakat keseluruhan. ${ }^{3}$ Adanya zakat yang dikeluarkan akan membawa kemuliaan bagi yang mengeluarkannya. Dalam Al Qur'an telah dijelaskan tidak kurang dari 27 tempat yang disejajarkan kewajiban salat dengan kewajiban zakat dalam berbagai bentuk kata di dalam Al Qur'an. ${ }^{4}$ Adanya hal tersebut menunjukkan bahwa zakat haruslah ditunaikan dengan sepenuh hati. Zakat diperoleh dari muslim kaya, kemudian digunakan oleh muslim yang fakir. Allah SWT juga mengatur lebih rinci siapa saja yang berhak menerima zakat sebagaimana tertera dalam Al-Qur'an surat at-Taubah ayat: $60 .{ }^{5}$

Negara Indonesia dalam pengelolaan zakat dijabarkan dalam Undang-Undang No. 38 tahun 1999 yang menyatakan bahwa peraturan perundang-undangan ini diberikan untuk mengoptimalkan potensi zakat sebagai pemasukan negara dalam mengentaskan kemiskinan. ${ }^{6}$ Undang-unadang nomor 38 di koreksi kembali dengan dengan dikeluarkannaya UURI Nomer 23 yang intinya adalah sama. Menurut data BPS (Badan Pusat Statistik) per September 2016 mencapai 27,76 juta orang $(10,70 \%)$ dari jumlah penduduk di negara Indonesia. ${ }^{7}$

Masih banyaknya tingkat kemiskinan di Indonesia ini menunjukan peranan zakat sangat diperlukan dalam pengentasan kemiskinan tersebut. Islam mengajarkan ummat untuk saling tolong menolong melalui zakat, infaq dan shadaqah. Tolong menolong tersebut tidak hanya di peruntukan bagi ummat Islam saja tetapi manfaat untuk seluruh umat yang ada di muka bumi ini.

Secara garis besar, zakat dapat diklasifikasi menjadi dua, yaitu, pertama: zakat mal (harta), yang menurut UU. Pengelolaan Zakat meliputi :(a) Emas, perak, dan uang,(b) Perdagangan dan perusahaan, (c). Hasil pertanian, perkebunan, dan perikanan, (d) Hasil pertambangan, (e) Hasil peternakan, (f) Hasil pendapatan dan jasa, (g) Rikaz (harta temuan). Kedua zakat fitrah/zakat al-Nafs, yakni zakat yang ditunaikan berkaitan dengan ibadah puasa ramadhan atau sebagai syarat diterimanya ibadah puasa ramadhan. Zakat ini dibebankan kepada setiap pribadi muslim, berupa makanan pokok, sebesar satu sha' (minimal setara dengan 2,5 kg)". ${ }^{8}$ Keberadaan zakat merupakan cara untuk mengentaskan kemiskinan dan memberikan rasa saling tolong menolong antar sesama di dunia ini.

\footnotetext{
${ }^{1}$ Alie Yafie, Menggagas Fiqh Sosial (Bandung, 1994).

2 "UNDANG-UNDANG REPUBLIK INDONESIA NOMOR 23 TAHUN 2011 TENTANG PENGELOLAAN ZAKAT pasal 1 ayat 2 ," t.t.

3 Abdurrahman Qadir, Zakat dalam Dimensi mahdhah dan social (PT Raja Grafindo persada, 1998).

4 Yusuf Qardawi, Fiqih Zakat (Bandung: Mizan, 1994).

5 Departemen Agama RI, Al Quran dan terjemahan, t.t.

6 "Undang-Undang no 38 tahun 1999," t.t.

7 “Sekretariat Kabinet Republik Indonesia," t.t., http://setkab.go.id/bps-per-sept.

8 M Sularno, "Pengelolaan Zakat Oleh Badan Amil Zakat Daerah Kabupaten/Kota Se Daerah Istimewa Yogyakarta (Studi terhadap Implementasi Undang-Undang No.38 Tahun 1999 tentang pengelolaan Zakat)," La Riba IV. No 1 (Juli 2010): 34-44.
} 
Menurut Nur Syam, pengelolaan zakat selama ini masih belum optimal, karena masih banyak perolehan zakat tidak maksimal. ${ }^{9}$ Pengelolaan yang baik pada lembaga amil zakat sangatlah diperlukan mengingat lembaga ini merupakan lembaga publik yang keberadaannya selalu menjadi pertanyaan bagi masyarakat khususnya muzakki. Salah satu meningkatkan kepercayaan masyarakat yang dilakukan para muzakki dengan memberikan laporan pertanggungjawaban berupa laporan keuangan lembaga amil zakat yang dikelola.

Keberadaan lembaga amil zakat di Pamekasan terdiri dari BAZDA (Badan Amil Zakat Daerah) Pamekasan, LAZBU (lembaga Amil Zakat Bina Ummat) dan Baitul Muttaqin Hidayatullah (BMH) serta beberapa LAZ lainnya yang dididrikan atas inisiatif masyarakat. Pengelolaan zakat oleh lembaga amil zakat yang ada di Pamekasan menurut bapak Apik (Ketua Komisi IV DPRD Pamekasan) dinilai kurang efektif karena hanya mengelola zakat dari Pegawai Negeri Sipil (PNS) di lingkungan Pemkab Pamekasan. ${ }^{10}$ Salah satu bentuk pengelolaan yang akan meningkatkan kepercayaan muzakki adalah dalam bentuk laporan pertanggungjawaban keuangan yang akuntabel.

Laporan keuangan yang akuntabel perlu dilakukan berdasarkan standar akuntansi keuangan yang berlaku umum, dalam hal ini adalah akuntansi zakat yang merujuk pada PSAK 109. Menurut Wibisono, Laporan pertanggungjawaban (keuangan) lembaga zakat kenyataan dalam prakteknya tidak seragam disebabkan tidak adanya standar. Amil zakat sebagai entitas umat harus bertanggungjawab kepada umat juga, harus lebih accountable, transparan, dan profesional di mata publik. ${ }^{11}$ hal tersebut menjadi penting untuk memberikan laporan pertanggungjawaban kepada publik khususnya para muzakki. Tujuan zakat diamanahkan oleh muzakki adalah mengentaskan kemiskinan.

Pencapaian Pengelolaan yang baik dapat dilakukan dengan memberikan laporan pertanggungjawaban yang akuntabel berdasarkan pelaporan yang benar. Pelaporan yang akuntebel akan membuat para muzakki merasa puas sehingga zakat berikutnya dapat diamanahkan kembali ke lembaga amil zakat tersebut.

Menurut Nikmatuniayah, ketidakpercayaan pembayar zakat (Muzakki) disebabkan belum transparansinya laporan penggunaan dana zakat untuk publik. Karena itu aturan pelaporan penggunaan dana zakat diperlakukan pada semua amil di Indonesia. ${ }^{12}$ Dalam AlQuran Surat Al-Baqarah (2):282 memberikan arahan sekaligus bukti terkuat bahwa Islam sangat mendorong untuk tertib administrasi dan tranparasi. Semua transaksi terlebih lagi yang future delivery. Harus ditulis secara benar dan detail. Hal ini tersurat dari penekanan perintah menulis yang diulang tak kurang dari 5 kali dalam 5 baris pesan. ${ }^{13}$

Pelaporan zakat yang diterima maupun yang dikeluarkan hendaklah mempunyai kesesuain dengan sistem pelaporan yang lazim dipakai. Adapun pelaporan tersebut berdasarkan standar akuntansi yang berlaku umum. Indonesia mempunyai standar pencatatan akuntansi berupa PSAK nomer 109 tentang akuntansi zakat.

Pelaporan yang benar akan membantu pihak amil zakat membuat laporan pertanggungjawaban yang benar sehingga dapat dijadikan acuan dalam rencana pendistribusian zakat dan pengelolaan ke depan. Adanya acuan dana yang ada akan membantu pihak penyetor zakat mengetahui rencana kedepan amil zakat. Laporan keuangan

\footnotetext{
9 "tiga-upaya-strategis-kemenag-kelola-zakat,"t.t., https://m.tempo.co/read/news/2016/04/05/090760008/. $10 \quad$ "nilai-pengelolaan-zakat-tidak-efektif-komisi-iv-dprd-pamekasan-wacanakan-susun-raperda/," t.t., http://radarmadura.co.id/2015/07/.

11 Jusuf Wibisono, "Rekor Manis PSAK Zakat," Majalah Akuntan Indonesia No.3 (Oktober 2011).

12 Nikmatuniayah., "Nikmatuniayah.. Perlunya Pelaporan Zakat untuk Publik, TEKNIS, Vol.5, No.2 Agustus 2010, pp.91-96.," TEKNIS 5 No 2 (Agustus 2010): 91-96.

13 Iwan Triyuwono, Perspektif,Metodologi,dan Teori Akuntansi Syariah Jakarta: PT Raja Grafindo persada, 2006.
} 
yang benar dan akuntabel membuat pihak amil zakat merasa sudah bekerja sesuai amanah yang diberikan para muzakki, sedangkan pihak muzakki merasa zakat yang dititipkan untuk dikelola sudah sesuai harapannya. Laporan keuangan badan amil zakat merupakan salah satu bentuk pertanggungjawabannya kepada pihak muzakki.

Pentingnya laporan pertanggungjawaban pihak amil zakat telah dilakukan oleh Sugiyarti. Dari hasil penelitian ini mencerminkan perlunya standar/regulasi yang mengatur praktik akuntansi pada OPZ (Organisasi Pengelola Zakat), terlebih mengenai pelaporan dan penyajian laporan keuangan, yang selama ini audit hanya merupakan himbauan sebagaimana dinyatakan dalam UU No. 38 Tahun 1999 pasal 5 tentang pengelolaan zakat. ${ }^{14}$ Hal tersebut selaras dengan penelitian Rachma Indrarini dan Aditya Surya Nanda, juga melakukan penelitian tentang pengelolaan zakat. Adapun hasil dari penelitian ini adalah Beberapa Muzakki belum menilai sistem yang digunakan oleh Organisasi Penerima Zakat baik, profesional dan amanah. Banyak muzakki yang menilai bahwa Organisasi Penerima Zakat belum akuntabel dan transparan. ${ }^{15}$ Adanyan regulasi dalam praktik akuntansi pada OPZ diharapkan akan meningkatkan kepercayaan pihak muzakki dalam menyerahkan zakat, infak dan shadaqah kepada pihak OPZ. Regulasi akan memberikan keteraturan dalam bekerja dan program.

Penelitian mengenai program kerja dalam pengelolaan zakat dilakukan juga oleh Nurul Huda, Tjiptohadi Sawarjuwono dalam Akuntabilitas Pengelolaan Zakat melalui Pendekatan Modifikasi Action Research Hasil penelitiannya menunjukkan tumpang tindihnya program pemberdayaan antar OPZ, data muzakki dan mustahiq tidak akurat, terbatasnya kemitraan OPZ, kebijakan pemerintah bertentangan dengan program pendayagunaan, belum didapatkan model promosi murah dan keterbatasan tenaga amil yang profesional. ${ }^{16} \mathrm{Hal}$ ini menunjukkan bahwa program kerja pemberdayaan dan data harus benar benar akurat. Tanpa adanya data yang akurat maka keberlanjutan sebuah kegiatan kurang baik atau tumpang tindih seperti hasil penelitian penjelasan di atas.

Penelitian mengenai pengungkapan laporan yang akuntabel telah dilakukan Sigit Hermawan Gianti Astriana dengan judul Akuntansi Zakat, Dan Upaya Peningkatan Transparansi Dan Akuntabilitas Lembaga Amil Zakat hasil penelitiannya menyatakan bahwa Data keuangan berupa laporan keuangan dapat disajikan dengan lengkap seperti teori yang diungkap, dengan penyajian laporan keuangan yang bersifat simple dan accountable. ${ }^{17}$

Penelitian program kerja juga dilakukan oleh Raja Adzrin Raja Ahmad Ahmad Marzuki Amiruddin Othman Muhammad Sufiyudin Salleh hasil penelitian adalah menunjukkan bahwa media utama informasi zakat adalah kata-kata yang diucapkan. Penemuan dalam penelitian ini dapat memberikan keuntungan bagi lembaga zakat untuk efesiensi evaluasi manajemen zakat dalam memepertemukan dengan penerima zakat. ${ }^{18}$

Penelitian sebelumnya inilah yang menginspirasi peneliti melakukan penelitian mengenai perlakuan akuntansi zakat menurut PSAK 109 dan penerapan UNDANG-UNDANG REPUBLIK INDONESIA NOMOR 23 TAHUN 2011 TENTANG PENGELOLAAN ZAKAT dalam

\footnotetext{
14 Sugiyanti Fatma Laela, “Analisis Faktor-Faktor Yang Mempengaruhi Kinerja Organisasi Pengelola Zakat,” TAZKIA Islamic Finance \& Business Review 5 No. 2 (Desember 2010).

15 Rachma Indrarini dan Aditya Surya Nanda, "Transparansi Dan Akuntabilitas Laporan Keuangan Lembaga Amil Zakat: Perspektif Muzaki Upz Bni Syariah,” AKRUAL Jurnal Akuntansi 8 No.2 (April 2017): 63-75.

${ }^{16}$ Nurul Huda dan Tjiptohadi Sawarjuwono, "Akuntabilitas Pengelolaan Zakat melalui Pendekatan Modifikasi Action Research," Jurnal akuntansi Multiparadigma JAMAL, Malang 4 Nomor 3 (2013): 330-37.

17 Sigit Hermawan dan Gianti Astriana , Akuntansi Zakat, Dan Upaya Peningkatan Transparansi Dan Akuntabilitas Lembaga Amil Zakat, Jurnal Ekonomi. Vol 1 No. 2. Nopember 2010, (Hlm 34 - 42)

18 Raja Adzrin Ahmad ahmad, Ahmad Marzuki Amiruddin Othman, dan Muhammad Sufiyudin Salleh, "Assessing the Satisfaction Level of Zakat Recipients Towards Zakat Management," INTERNATIONAL ACCOUNTING AND BUSINESS CONFERENCE 2015, IABC Procedia Economics and Finance, 2015, 140-51.
} 
Penguatan Good Corporate. Adapun titik pembedaan dari penelitian terdahulu adalah melakukan penelitian perlakuan akuntansi zakat menurut PSAK 109 dan sekaligus mengevaluasi penerapan UNDANG-UNDANG REPUBLIK INDONESIA NOMOR 23 TAHUN 2011 TENTANG PENGELOLAAN ZAKAT dalam penguat terciptanya good corporate lembaga amil zakat. Jika Hal tersebut terjadi diharapkan dapat meningkatkan para muzakki memberikan amanah zakatnya ke lembaga tersebut, sedangkan penelitian terdahulu melakukan evaluasi secara terpisah antara PSAK 109, Standar AAOFI FAS 9, UNDANG-UNDANG REPUBLIK INDONESIA NOMOR 23 TAHUN 2011 TENTANG PENGELOLAAN ZAKAT dan kepuasan pihak penerima zakat terhadap pengelola zakat ('amil zakat).

Dari latar belakang di atas, maka penelitian ini mengambil tema tentang perlakuan akuntansi zakat PSAK 109 dalam penguatan good corporate Lembaga Amil Zakat di kabupaten Pamekasan. Peneliti ini membahas pelaporan data keuangan lembaga amil zakat berdasarkan akuntansi zakat yang merujuk pada PSAK no 109 dan UNDANG-UNDANG REPUBLIK INDONESIA NOMOR 23 TAHUN 2011 TENTANG PENGELOLAAN ZAKAT. Penelitian ini merupakan kajian ekonomi dalam arti sempit khususnya akuntansi zakat. Penelitian ini diharapkan dapat menjelaskan Bagaimana perlakuan akuntansi zakat dan penerapan pengelolaan zakat berdasarkan UNDANG-UNDANG REPUBLIK INDONESIA NOMOR 23 TAHUN 2011 TENTANG PENGELOLAAN ZAKAT untuk penguatan Good Corporate Di Kabupaten Pamekasan.

Hasil penelitian ini diharapkan dapat menambah khasanah dalam pelaporan pertanggungjawaban keuangan dalam pengelolaan dana zakat, sekaligus memberi masukan dalam pertanggung jawaban pihak lembaga amil zakat berupa laporan keuangan yang akuntabel terhadap muzakki. Di samping itu, diharapkan good corporate lembaga amil zakat bisa terwujud sehingga tingkat kepercayaan muzakki semaikn tinggi, serta dijadikan rujukan untuk penelitian pelaporan pertanggungjawaban keuangan perusahaan nirlaba.

\section{METODE PENELITIAN}

Metode penelitian ini adalah penelitian diskriptif kualitatif. Penelitian ini menjelaskan tentang perlakuan akuntansi merujuk pada aturan yang ada pada PSAK 109 mengenai akuntansi zakat dan kemudian mengevaluasi penerapan UNDANG-UNDANG REPUBLIK INDONESIA NOMOR 23 TAHUN 2011 TENTANG PENGELOLAAN ZAKAT. Obyek penelitian dalam penelitian ini adalah badan amil zakat yang mempunyai surat keputusan secara nasioanal dalam hal pengelolaan dana zakat.

Teknik pengumpulan data yang digunakan adalah dengan dokumentasi, interview, observasi, terhadap BAZNAS (Badan Amil Zakat Nasional) Kabupaten Pamekasan, LAZMU (Lembaga Amil Zakat Muhammadiyah) Pamekasan dan BMH (Baitul Maal Hidayatullah) Pamekasan di Pamekasan.

Data dalam penelitian ini adalah data primer yang diperoleh melalui interview, observasi, sedangkan data sekunder diperoleh melalui literature, buku, jurnal serta kajian ilmiah yang sesuai dengan topik penelitian ini. Adapun teknik analisis data yang akan dilakukan melalui analisa deskriptif kualitatif. Teknik ini dilakukan dengan melihat perlakuan pencatatan akuntansi dalam pengakuan dan pengukuran pendapatan menurut catatan dari perusahaan (Lembaga Amil Zakat) yang kemudian dibandingkan menurut perlakuan akuntansi dalam PSAK 109 mengenai akuntansi zakat.

\section{HASIL DAN PEMBAHASAN}

Pembayaran zakat oleh seorang muslim merupakan kewajiban sebagaimana ditegaskan dalam salah satu ayat di dalam Al-Qur'an yang berhubungan dengan perintah 
zakat adalah surat al-Baqarah (2) yang artinya: "Hai orang-orang yang beriman, nafkahkanlah (di jalan Allah) sebagian dari hasil usahamu yang baik-baik dan sebagian dari apa yang kami keluarkan dari bumi untuk kamu. Dan janganlah kamu memilih yang buruk-buruk lalu kamu menafkahkan daripadanya, padahal kamu sendiri tidak mau mengambilnya melainkan dengan memincingkan mata terhadapnya. Dan ketahuilah, bahwa Allah Maha Kaya lagi Maha Terpuji." [QS. al-Baqarah (2): 267] ${ }^{19}$. Hal ini menunjukkan bahwa sebagian harta yang dimiliki oleh seorang muslim terdapat sebagian hak orang lain yang harus disalurkannya.

Penelitian ini membahas perlakuan akuntansi zakat berdasarkan PSAK no 109 dan mengevaluasi penerapan UNDANG-UNDANG REPUBLIK INDONESIA NOMOR 23 TAHUN 2011 TENTANG PENGELOLAAN ZAKAT. Mengenai pemahaman tentang zakat, definisi dan siapa yang berhak menerima zakat atau para mustahiq yang delapan kelompok (delapan ashnaf) pihak Baitul Maal Hidayatullah(BMH), Lemaga Amil Zakat Muhammadiyah (LAZISMU) dan Badan Amil Zakat Nasional (BAZNAS) kabupaten Pamekasan pada dasarnya telah paham. Pemahaman tersebut menyangkut juga pada berapa besaran yang harus diabayar pihak muzakki terhadap zakat hartanya. Adanya pemahaman tentang perhitungan zakat bagi para muzakki, maka akan menjadi penolong bagi muzakki untuk memperhitungkan zakat yang seyogyanya harus dikeluarkan. Zakat adalah sebagai pembersih harta bagi umat muslim.

Kedelapan ashnaf tersebut terdiri dari :Fakir, Miskin, Riqab, Orang yang terlilit utang (gharim), Mu'allaf, Fisabillilah, orang dalam perjalanan (ibnu sabil) dan 'Amil. Dari kedelapan ashnaf yang ada, penyaluran zakat dari ketiga lembaga zakat tersebut paling banyak untuk fakir, miskin, fisabilillah dan amil. Untuk kelompk gharim pihak lembaga amil zakat pernah melakukannya dan tetapi tidak sering. Kegiatannya tidak sesering pada ke empat kelompok yang disebutkan di atas.

Penyaluran zakat bagi mu'allaf, riqab cenderung jarang disalurkan hampir tidak ada kecuali di pusat, sedangkan untuk dana zakat fisabilillah biasanya diberikan berupa beasiswa untuk masyarakat yang tidak mampu seperti yang dilakukan pihak BMH dan LAZISMU. Pihak lembaga tersebut memberdayakan anak yang mendapatkan beasiswa untuk ikut terjun dalam lembaga zakat tersebut.

Pihak muzakki dari BAZDA kabupaten Pamekasan berasal dari para PNS, Pegawai BUMN, BUMD di kabupaten Pamekasan sedangkan pihak BMH dan LAZISMU berasal dari para donatur masyarakat dan pegawai swasta. Kecenderungan zakat yang diberikan berupa zakat tunai. Zakat non tunai yang ada hanya pada zakat fitrah.

Pada saat ini kecenderungan orang (para muzakki) memberikan secara tunai dengan cara menyetor ke bank melalui nomer rekening atas nama lembaga zakat tersebut atau langsung ke kantor lembaga zakat. Ketiga lembaga tersebut juga mempunyai program jemput bola, dengan maksud pihak lembaga akan menjemput dana ZIS jika pihak muzakki meminta untuk mengambilnya ke rumah.

Adapun Prosedur perlakuan akuntansi berdasarkan PSAK 109 yang terjadi di ke-3 (tiga) lembaga tersebut sebagai berikut:

\section{Pengakuan dan Pengukuran Pengakuan Awal}

Perlakuan akuntansi pada zakat diakui saat kas atau aset lainnyanya diterima. Pada konsep ini ketiga lembaga tersebut telah paham dan telah menjurnalnya sesuai perlakuan akuntansi yang lazim. Jika dalam melakukan penjurnalan benar maka hasil akhir yang diperoleh akan menjadi acuan benar untuk perencanaan kedepan.

${ }^{19}$ Departemen Agama RI.. Al-Qur'anul Terjemah per Kata. Syaamil Al-Qur'an, Bandung, 2007. 
Perlakuan zakat yang diterima dari muzakki diakui sebagai penambah dana zakat, Jika dalam bentuk kas maka sebesar jumlah yang diterima sedangkan jika dalam bentuk nonkas maka sebesar nilai wajar aset non kas tersebut. Pada perlakuan zakat ini ketiga lembaga telah paham bahwa ketika ada penerimaan zakat maka akan dicatat menjadi penambah sesuai dana tunai yang diterima, jika non tunai yang diperoleh maka nilainya di konversi ke harga pasar pada saat itu, seperti perlakuan pada zakat fitrah yang di konversi dengan nilai pasar pada saat pembayaran. Konversi zakat telah dilakukan ke-3 (tiga) lembaga amil zakat itu.

Zakat yang diterima diakui sebagai dana 'amil untuk bagian 'amil dan dana zakat untuk bagian non 'amil. Ketiga lembaga zakat telah melakukan pembuatan laporan zakat untuk amil zakat. Laporan tersebut terlihat pada laporan keuangan yang dibuat dengan dicantumkanya nama akun tersendiri untuk bagian amil dan bagian non amil. Penentuan besaran untuk amil telah sesuai dengan syariah dan keputusan atau kebijakan lembaga tersebut. Penentuan besaran untuk 'amil menjadi penting untuk perhitungan dana zakat yang masuk kelembaga termasuk juga pekerjaan yang dilakukan oleh amil zakat agar para muzakki mendapatkan kepuasan dalam penyaluran zakatnya.

Jika muzakki menentukan mustahiq yang harus menerima penyaluran zakat melalui 'amil, maka aset zakat yang diterima seluruhnya diakui sebagai dana zakat, jika atau jasa tersebut 'amil mendapatkan ujrah/fee maka diakui sebagai penambah dana 'amil. Pada konsep ini pihak lembaga telah mengetahui dan paham sehingga perlakukan terhadap penerimaa zakat yang telah ditentukan muzakki untuk para mustahiq otomatis menjadi dana zakat semua kecuali fee yang diberikan maka menjadi bagian pihak amil.

\section{Pengukuran Setelah Pengakuan Awal}

Jika terjadi penurunan nilai asset pada nonkas, jumlah kerugian yang ditanggung harus diperlakukan sebagai pengurang dana zakat atau pengurang dana amil tergantung dari sebab terjadinya kerugian. konsep ini pihak lembaga BMH dan BAZNAS kurang paham mengenai penurunan aset hanya pada lembaga LAZISMU yang paham bahwa jika penurunan karena akibat kelalaian amil maka dana amil yang berkurang bukan karena kelalaian amil maka dana zakat yang berkurang. Pada pemahaman ini pihak kedua lembaga yaitu BMH dan BAZNAS kabupaten hanya menjawab jika dana berkurang maka akan mengurangi dana ZIS. Pemahaman tersebut wajar karena SDM pada lembaga tersebut bagroundnya bukan ekonomi.

Adanya perlakuan tanggung jawab terhadap kelalaian atau penurunan aset zakat maka akan memberikan dampak padak pelaporan yang dibuat. Pelaporan tersebut akan menjadi acuan bagi para muzakki memeutuskan penyaluran yg diamanahkannya untuk dikelola.

\section{Penyaluran Dana}

Zakat yang disalurkan kepada mustahiq diakui sebagai pengurang dana zakat sebesar jumlah yang diserahkan jika dalam bentuk kas dan jumlah tercatat sebesar jika dalam bentuk aset non aset. Pada perlakuan akuntansi ini pihak lembaga sudah paham dan menerapkannya dalam pencatatan seperti hasil wawancara dari bapak Matnin (LAZISMU). Bapak Azis (BAZNAS) kabupaten Pamekasan, dan bapak Idris (BMH). Penerimaan zakat non tunai yang dikonversikan dengan harga pasar pada saat itu. Biasanya terjadi hanya pada zakat fitrah.

Pertama;Dana Non halal. Pada konsep penerimaan dana non halal ketiga lembaga tersebut mengerti dan paham karena akun rekening yang ada telah membedakannya antara rekening non halal atau rek non syariah. Perbedaan ini akan memberikan dampak adanya 
ketidakcampuran dana halal dan non halal. Dana non halal yang dimaksud adalah dana zakat yang ditempatkan pada bank konvensional. Bank konvesional masih menggunakan sistem bunga yang dilarang oleh agama.

Kedua; Penerimaan non halal diakui sebagai dana non halal, yang terpisah dari dana zakat, dana infak/sedekah dan dana 'amil. Aset non halal disalurkan sesuai syariah. Hal ini telah diterapkan seperti penjelasan di atas, bahwa ketiga lembaga telah melakukannya dengan membentuk akun rekening non halal dan halal. Pada rekening di BMH terdapat dana yang tersimpan pada bank umum, sehingga pendapatan bunga dimasukkan pada rekening non halal. ${ }^{20}$

\section{Penyajian}

'Amil menyajikan dana zakat, dana infak/sedekah, dana amil dan dana non halal secara terpisah dalam neraca (laporan posisi keuangan). Pada bentuk penyajian ketiga lembaga zakat tersebut telah melakukan dalam penyajian laporan keuangannya, karena setiap akun tersebut disajikan terpisah. Pemisahan terhadap akun pada setiap posisi keuangan dimaksudkan untuk memberikan penjelasan dari penerimaan dan pengeluaran lebih detil atau komprehensif.

\section{Pengungkapan}

'Amil harus mengungkapkan hal-hal berikut terkait dengan transaksi zakat tetapi tidak terbatas pada: 1) Kebijakan penyaluran zakat, seperti penentuan skala prioritas penyalur dan penerima; 2) Kebijakan pembagian antara dana amil dan dana non amil atas penerimaan zakat, seperti persentase pembagian, alasan dan konsistensi kebijakan; 3) Metode penentuan nilai wajar yang digunakan untuk penerimaan zakat berupa aset non kas; 4) Rincian jumlah penyaluran dana zakat yang mencakup jumlah beban pengelolaan dan jumlah dana yang diterima langsung mustahiq; dan 5) Hubungan istimewa antara 'amil dan mustahiq yang meliputi; a) Sifat hubungan istimewa; b) Jumlah dan dana jenis aset yang disalurkan; dan c) Presentase dari aset yang disalurkan tersebut dari total penyaluran selam periode.

Pada pengungkapan pihak 'amil telah mengungkapannya dalam laporan keuangan dan memberikan laporan berupa bulletin kepada pihak donator serta muzakki. Pengungkapan kepada pihak 'amil telah dilakukan oleh ketiga 'amil zakat tersebut sebagai bentuk tanggung jawab atas pengelolaannya kepada pihak muzakki. Adanya pelaporan yang berbentuk bulletin dan laporan posisi keuangan yang sederhana akan memberikan nilai positif dalam penciptaan akuntabilitas dan transparasi dalam pengelolaan. Pengelolaan yang baik akan menunjang pencapaian tujuan dari sebuah lembaga.

Perlakuan zakat yang dijelaskan di atas, juga sama dilakukan terhadap infaq, shadaqah dan wakaf. Transaksi yang sering terjadi pada ketiga lembaga tersebut adalah penerimaan zakat, infaq dan shadaqah kemudian menyalurkan kepada delapan ashnaf yang ada. Hanya saja ashnaf riqab dan mu'allaf yang masih belum ada. Tetapi ashnaf mu'allaf dan riqab pernah dilakukan di pusat yaitu LAZISMU dan BMH.

Adapun Laporan keuangan yang dilaporkan oleh ketiga lembaga amil zakat tersebut sebagai berikut:

\section{Baitul Maal Hidayatullah (BMH)}

Adapun laporan keuangan yang disajikan terdiri dari: 1) laporan bulanan dan tahunan berupa Laporan Neraca; 2) Laporan sumber dan penggunaan dana zakat; 3) Laporan

\footnotetext{
20 Wawancara dengan bapak idris tanggal 19 september 2017
} 
sumber dan penggunaan dana infak; 4) Laporan sumber dan penggunaan dana shadaqah; 5) Laporan sumber dan penggunaan dana wakaf; 6) Laporan sumber dan penggunaan dana amil. Sedangkan laporan perubahan dana, laporan perubahan aset kelolaan dan catatan akunatnsi masih belum dilakukan hal ini menunjukkan laporan yang dibuat sebatas neraca dan peneriman serta pengeluaran kas.

\section{LAZISMU (Lembga Amil Zakat Muhammadiyah)}

Adapun laporan keuangan yang disajikan terdiri dari: 1) Laporan bulanan dan tahunan berupa Laporan posisi keuangan; 2) Laporan arus kas. Sedangkan laporan perubahan dana, laporan perubahan aset kelolaan dan catatan atas laporan keuangan belum dilakukan oleh pihak LAZISMU.

Sementara bagi pihak BAZNAS kabupaten Pamekasan hanya berupa laporan penerimaan dan pengeluaran, hal ini menunjukkan bahwa komponen laporan keuangan masih belum dilakukan.

\section{BAZNAS Kabupaten Pamekasan}

Adapun laporan keuangan yang disajikan hanya pada penerimaan dan pengeluaran saja. Laporan tersebut dibuat pada program excel terlebih dahulu, baru kemudian diinput sesuai dengan program yang langsung online pusat baznas. Hasil laporan keuangan yang disajikan selaras.

Dari ketiga poin pengakuan dan pengukuran, penyajian dan pengungkapan dalam pencatatan akuntasi berdasarkan PSAK 109 telah melakukannya, tetapi kurang lengkap. Ketiga lembaga tersebut dalam melakukan pencatatan akuntansi sudah paham debet dan kreditnya. Dalam membuat sebuah laporan keuangan pihak amil masih belum sepenuhnya menyajikan kelima komponen laporan keuangan yang lengakp.

Hasil penelitian ini selaras dengan penelitian Istutik yang berjudul analisis implementasi akuntansi zakat daninfak/sedekah (psak:109) pada lembaga amil zakat di kota Malang. Hasil penelitiannya penerimaan dan penyaluran dana zakat, infak, dan sedekah telah dilakukan oleh lembaga amil di kota Malang. Namun lembaga amil belum menerapkan standar akuntansi ZIS (PSAK 109) untuk penyusunan laporan keuangannya. Disisi lain pertanggungjawaban keuangan yang dimaksud masih sebatas laporan penerimaan dan pengeluaran kas. ${ }^{21}$

Selanjutnya hasil penelitian serupa telah dilakukan oleh Pandapotan Ritonga dengan judul Analisis Akuntansi Zakat Berdasarkan Psak No. 109 Pada Badan Amil Zakat Nasional (Baznas) Sumatera Utara, Hasil penelitian menunjukan bahwa BAZNAS Sumatera utara tidak melaksanakan secara menyeluruh penerapan akuntansi PSAK no 109 Laporan keuangan yang disajikan oleh BAZNAS Sumatera Utara karena masih belum informatif, hal ini disebabkan perlakuan akuntansi zakat belum sepenuhnya sesuai dengan PSAK NO. 109.22

Situasi dari keadaan tersebut disebabkan salah satunya karena SDM yang masih kurang paham dalam pembuatan laporan keuangan yang disebabkan background keilmuan karyawan. Oleh sebab itu perlu dilakukan pelatihan-pelatihan setahap-demi setahap sehingga apa yang kurang dapat terwujud.

\footnotetext{
21 Istitutik, Analisis Implementasi Akuntansi Zakat Dan Infak/Sedekah (Psak:109) Pada Lembaga Amil Zakat Di Kota Malang, Jurnal Akuntansi Aktual, Vol. 2, Nomor 1, Januari 2013, hlm. 19-24

22 Pandapotan Ritonga, "Pandapotan Ritonga dengan judul Analisis Akuntansi Zakat Berdasarkan Psak No. 109 Pada Badan Amil Zakat Nasional (Baznas) Sumatera Utara, Jurnal Kitabah: Volume 1. No. 1 Januari - Juni 2017 Hal 1-20," Kitabah 1 No 1 (Juni 2017): 1-20.
} 
Adanya SDM yang kurang memahami dalam pencatatan akuntansi akan membawa hasil laporan kurang akurat. Masih kurangnya SDM dalam pengelolaan zakat baik selaras dengan hasil penelitian Nurul Huda, Tjiptohadi Sawarjuwono dalam Akuntabilitas menunjukkan tumpang tindihnya program pemberdayaan antar OPZ, data muzaki dan mustahik tidak akurat, terbatasnya kemitraan OPZ, kebijakan pemerintah bertentangan dengan program pendayagunaan, belum didapatkan model promosi murah dan keterbatasan tenaga amil yang profesional. ${ }^{23}$ Sumber daya manusia yang profesional dan mengerti terhadap pekerjaannya akan membawa lembaga menjadi lebih terarah dan maju.

Kepatuhan menurut UNDANG-UNDANG REPUBLIK INDONESIA NOMOR 23 TAHUN 2011 TENTANG PENGELOLAAN ZAKAT kecenderungan pihak lembaga zakat yang ada di cabang berusaha untuk mengikutinya meskipun kadang tidak sesuai seperti pelaporan harus mengikuti 5 (lima) komponen laporan keuangan. Pihak cabang selalu melaporkan hasil kegiatannya kepusat. Oleh sebab itu perlu dilakukan pelatihan-pelatihan setahap-demi setahap sehingga pelaporan sesuai dengan standart.

Perlakuan akuntansi yang benar akan membawa hasil laporan yang dibuat menjadi lebih akuntabel sehingga good corporate dari lembaga akan tercapai. Tanpa adanya proses yang benar maka hasilnya akan menjadi kurang benar. Seandainya laporan tersebut akan dijadikan pedoman strategi atau rencana ke depan maka akan menjadi salah. Seperti hasil penelitian Dr. Adel Mohammed Sarea (2015) menjelaskan tentang penerapan akuntansi zakat berdasarkan AAOIFI FAS 9 (Financial Accounting Standard No 9) hasil penelitiannya menjelasakan bahwa penerapan AAOFI sebagai standar untuk lembaga keuangan islam merupakan pilihan yang terbaik untuk meningkatkan investasi dan kepercayaan investor masyarakat muslim dalam menaikan jumlah zakat yang terkumpul. ${ }^{24}$

Penelitian Adel Selaras dengan penelitian yang dilakukan oleh Sigit Hermawan Gianti Astriana dengan judul Akuntansi Zakat, Dan Upaya Peningkatan Transparansi Dan Akuntabilitas Lembaga Amil Zakat hasil penelitiannya menyatakan bahwa Data keuangan berupa laporan keuangan dapat disajikan dengan lengkap seperti teori yang diungkap, dengan penyajian laporan keuangan yang bersifat simple dan accountable. ${ }^{25}$

Menurut Mardiasmo (2009) menjelaskan bahwa karakteristik pelaksanaan Good corporate adalah Participation, Rule of law, Transparency, Responsiveness, Consensus orientation, Equity, Efficiency dan effectiveness., Accountability, dan Strategic vision. ${ }^{26}$ Semua karakteristik dari good corporate, pelaksanaan, sampai proses pencatatannya di lakukan dengan benar dan sesuai kaidah yang benar, maka mungkin good corporate suatu lembaga akan terjadi.

\section{PENUTUP}

Berdasarkan pembahasan di atas maka simpulan pelaporan data keuangan lembaga amil zakat berdasarkan akuntansi zakat yang merujuk pada PSAK no 109 dan UNDANGUNDANG REPUBLIK INDONESIA NOMOR 23 TAHUN 2011 TENTANG PENGELOLAAN ZAKAT dalam rangka penciptaan good corporate adalah laporan pertanggungjawaban pihak 'amil zakat dapat dilihat berdasarkan laporan keuangan yang dibuat, hanya saja laporan keuangan yang dikeluarkan masih kurang dari komponen keuangan yang lazim dikeluarkan oleh lembaga zakat menurut PSAK 109. Pihak Lembaga telah berusaha untuk mengikuti

\footnotetext{
${ }^{23}$ Huda dan Sawarjuwono, "Akuntabilitas Pengelolaan Zakat melalui Pendekatan Modifikasi Action Research,."

${ }^{24}$ Adel Mohammed sarae, "Accounting Treatment of Zakah: Additional Evidence from AAOIFI," Journal of Islamic Banking and Finance, 1 No 1 (Desember 2013): pp (23-28) American research institute for policy development.

25 Sigit Hermawan dan Gianti Astriana, "Akuntansi Zakat, Dan Upaya Peningkatan Transparansi Dan Akuntabilitas Lembaga Amil Zakat," Jurnal Ekonomi 1 no. 2 (Nopember 2010): Hlm 34-42.

${ }^{26}$ Mardiasmo, Akuntansi Sektor publik (Yogyakarta: Andi, 2009).
} 
pengelolaan zakat meskipun ada beberapa hal yang masih belum paham. Hali ini menjadi catatan bagi pengelola untuk meningkatkan skill dalam proses pencatatan sesuai kaidah akuntansi yang lazim dipakai, sehingga laporan keuangan yang dibuat dapat dijadikan acuan untuk strategi ke depan dan terciptannya good corparate lembaga zakat yang diidamkan. Sebagi masukan bagi para peneliti yang ingin meneliti tentang perlakukan akuntansi zakat hendaknya lebih mengeksplore setiap transaksi zakat yang terjadi, sehingga diketahui sejauh mana konsep akuntansi zakat terpenuhi.

\section{DAFTAR PUSTAKA}

Ahmad, Raja Adzrin Ahmad, Ahmad Marzuki Amiruddin Othman, dan Muhammad Sufiyudin Salleh. "Assessing the Satisfaction Level of Zakat Recipients Towards Zakat Management." INTERNATIONAL ACCOUNTING AND BUSINESS CONFERENCE 2015, IABC Procedia Economics and Finance, 2015, 140-51.

Departemen Agama RI. Al Quran dan terjemahan, t.t.

Hermawan, Sigit, dan Gianti Astriana. "Akuntansi Zakat, Dan Upaya Peningkatan Transparansi Dan Akuntabilitas Lembaga Amil Zakat,." Jurnal Ekonomi 1 no. 2 (Nopember 2010): Hlm 34-42.

Huda, Nurul, dan Tjiptohadi Sawarjuwono. "Akuntabilitas Pengelolaan Zakat melalui Pendekatan Modifikasi Action Research,." Jurnal akuntansi Multiparadigma JAMAL, Malang 4 Nomor 3 (2013): 330-37.

Indrarini, Rachma, dan Aditya Surya Nanda. "Transparansi Dan Akuntabilitas Laporan Keuangan Lembaga Amil Zakat: Perspektif Muzaki Upz Bni Syariah,." AKRUAL Jurnal Akuntansi 8 No.2 (April 2017): 63-75.

Laela, Sugiyanti Fatma. "Analisis Faktor-Faktor Yang Mempengaruhi Kinerja Organisasi Pengelola Zakat." TAZKIA Islamic Finance \& Business Review 5 No. 2 (Desember 2010).

Mardiasmo. Akuntansi Sektor publik. Yogyakarta: Andi, 2009.

Nikmatuniayah. "Nikmatuniayah.. Perlunya Pelaporan Zakat untuk Publik, TEKNIS, Vol.5, No.2 Agustus 2010, pp.91-96." TEKNIS 5 No 2 (Agustus 2010): 91-96.

"nilai-pengelolaan-zakat-tidak-efektif-komisi-iv-dprd-pamekasan-wacanakan-susunraperda/," t.t. http://radarmadura.co.id/2015/07/.

Qadir, Abdurrahman. Zakat dalam Dimensi mahdhah dan social. PT Raja Grafindo persada, 1998.

Qardawi, Yusuf. Fiqih Zakat. Bandung: Mizan, 1994.

Ritonga, Pandapotan. "Pandapotan Ritonga dengan judul Analisis Akuntansi Zakat Berdasarkan Psak No. 109 Pada Badan Amil Zakat Nasional (Baznas) Sumatera Utara, Jurnal Kitabah: Volume 1. No. 1 Januari - Juni 2017 Hal 1-20." Kitabah 1 No 1 (Juni 2017): 1-20.

Sarae, Adel Mohammed. "Accounting Treatment of Zakah: Additional Evidence from AAOIFI." Journal of Islamic Banking and Finance, 1 No 1 (Desember 2013): pp (23-28) American research institute for policy development.

"Sekretariat Kabinet Republik Indonesia," t.t. http://setkab.go.id/bps-per-sept.

Sularno, M. "Pengelolaan Zakat Oleh Badan Amil Zakat Daerah Kabupaten/Kota Se Daerah Istimewa Yogyakarta (Studi terhadap Implementasi Undang-Undang No.38 Tahun 1999 tentang pengelolaan Zakat)." La Riba IV. No 1 (Juli 2010): 34-44.

"tiga-upaya-strategis-kemenag-kelola-zakat,"

t.t. https://m.tempo.co/read/news/2016/04/05/090760008/.

Triyuwono, Iwan. Perspektif,Metodologi,dan Teori Akuntansi Syariah. Jakarta: PT Raja Grafindo persada, 2006. 
"Undang-Undang no 38 tahun 1999," t.t.

"UNDANG-UNDANG REPUBLIK INDONESIA NOMOR 23 TAHUN 2011 TENTANG PENGELOLAAN ZAKAT pasal 1 ayat 2," t.t.

Wibisono, Jusuf. "Rekor Manis PSAK Zakat.” Majalah Akuntan Indonesia No.3 (Oktober 2011). Yafie, Alie. Menggagas Fiqh Sosial. Bandung, 1994. 